\title{
Increasing bitterbrush nutrient quality with 2,4- $D$, mowing, and burning in southcentral Wyoming
}

\author{
VINCENT M. KITUKU, JEFF POWELL, MICHAEL A. SMITH, AND RICHARD A. \\ OLSON
}

Authors are graduate student, professor, associate professor, and assistant professor, Department of Range Management, University of Wyoming, Laramie 82071.

\begin{abstract}
Effects of burning, mowing, and 2,4-D on antelope bitterbrush (Purshia tridentata Pursh.) nutrient contents were evaluated in southcentral Wyoming. During the first growing season following treatments, spraying of 2,4-D increased bitterbrush nitrogen (N) contents from 1.5 to $1.9 \%$, phosphorus (P) from 0.12 to $0.15 \%$, and in vitro digestible dry matter (IVDDM) from 44.1 to $\mathbf{4 8 . 4 \%}$. Mowing increased $\mathrm{N}$ from 1.5 to $1.7 \%$, $P$ from 0.12 to $0.16 \%$, and IVDDM from 44.1 to $46.1 \%$. Burning increased $\mathrm{N}$ from 1.4 to $1.9 \%, P$ from 0.11 to $0.17 \%$, ash from 3.7 to $5.3 \%$, and IVDDM from 47.4 to $51.0 \%$, and decreased gross energy from 4,640 to 4,380 kcal/g. There were no differences in N and IVDDM contents among treatments at the end of the second growing season, but $P$ content was still greater in mowed bitterbrush regrowth than on untreated bitterbrush. Ash contents were not affected by treatments, but were higher in summer $(3.9 \%)$ than in winter (2.4\%). Gross energy contents varied only 5 to $10 \%$ among all treatments and seasons. Correlation coefficients between N, P, ash, and IVDDM contents varied from +0.54 to +0.76 , and all of these nutrients were negatively correlated with gross energy. Bitterbrush nutrient contents can be increased by shrub management practices, but short-term responses require that small portions of the total area be treated annually in a rotational shrub management program.
\end{abstract}

Key Words: forage quality, chemical composition, range improvements, habitat improvement, shrub management

Antelope bitterbrush ( Purshia tridentata Pursh.) is highly palatable and nutritionally adequate for sheep (Ovis aries), cattle (Bos taurus), mule deer (Odocoileus hemionus), and elk (Cervus elaphus) in mixed shrub communities in the western United States (Hormay 1943). Bitterbrush is especially important in the fall and winter diets of mule deer because of its relatively high crude protein content. However, the nutrient quality of bitterbrush varies among plant parts and with age, with season, or phenology, and often influences palatability (Giunta et al. 1978, Tueller 1979).

Bitterbrush plants provide relatively high amounts of energy in late winter compared to other shrubs, but shrubs, in general, are relatively low in gross or metabolizable energy in the winter compared to cured, arid-land grasses. Forage cellulose levels may restrict energy and dry matter digestibility in ruminants enough to slow food consumption rates and passage, thus making energy nutrients in shrubs relatively unavailable to satisfy maintenance or production requirements (Dietz 1972).

Various range improvement practices offer opportunities to improve forage quality for wildlife and livestock on summer and fall ranges (Halls and Crawford 1965). Selective control of species with herbicides allows the manager to maintain vegetation in

\footnotetext{
The research was funded in part by USDA CSRS/IPM Grant 85-CSRS-2-2702.
} Manuscript accepted 9 Dec. 1991. almost any seral condition. Basal sprouting of decadent browse plants can be stimulated by killing the aerial crowns with chemicals (Mueggler 1966).

Mixed stands of big sagebrush (Artemisia tridentata Nutt.) and bitterbrush may be sprayed with 2,4-D without excessive bitterbrush loss if sprayed before or during bitterbrush bloom (Hyder and Sneva 1962). Mowing bitterbrush results in extensive root and leaf regeneration with subsequently greater utilization of rejuvenated browse. Rotocutting bitterbrush in early spring resulted in a $47 \%$ increase in leader growth during the first growing season (Schneegas and Zufelt 1965).

Greater forage availability occurs where regrowth of burned plants become more palatable than unburned plants, where physical barriers to utilization are removed, or where large plants are reduced in size by burning. Most prescribed fires cause an increase in protein content, digestibility, and palatability of resprouting shrubs (Dewitt and Derby 1955, Pearson et al. 1972, Short et al. 1972).

This study was conducted to determine how spraying with 2,4$D$, mowing, and burning would affect the summer and winter nutrient contents of bitterbrush in southcentral Wyoming.

\section{Methods}

\section{Study Area}

The study was conducted on the Cedar Creek Ranch, $20 \mathrm{~km}$ east of Saratoga, Wyo., on the western edge of the Medicine Bow Mountain Range. The elevation ranges from 2,100 to $2,600 \mathrm{~m}$. Soils are North Park Formation brown sandy loams developed on loess, limestone, sandstone, and tuff (Dunnewald 1957).

Dominant plant species include bitterbrush, mountain big sagebrush (Artemesia tridentata spp. vaseyana Nutt.), Idaho fescue (Festuca idahoensis Elmer), sandberg bluegrass (Poa secunda Presl.), canby bluegrass [ $P$. canbyi (Scribn.) Howell], western wheatgrass [Pascopyrum smithii (Rydb.) A. Love], bluebunch wheatgrass [Pseudoroegneria spicata (Pursh) Love], and thickspike wheatgrass [Elymus lanceolatus (Scriber and J.G. Smith) Gould].

Precipitation ranges from 380 to $\mathbf{4 8 0} \mathrm{mm}$ and occurs mostly as snow. The Saratoga weather station, located $25 \mathrm{~km}$ west of the study area at a drier and lower location, reports precipitation of generally less than $20 \mathrm{~mm} /$ month from November through March, and 20 to $30 \mathrm{~mm} /$ month from April through October. Annual depth and extent of snow coverage is highly variable. Elk and mule deer utilize the area during fall and winter in some years, but only during fall in those years with greater snow depth and duration.

\section{Experimental Design}

Preliminary soil and vegetation surveys were conducted to select 16 relatively homogeneous areas. Each area was ranked along a soil type, dominant shrub cover, and species composition gradient 


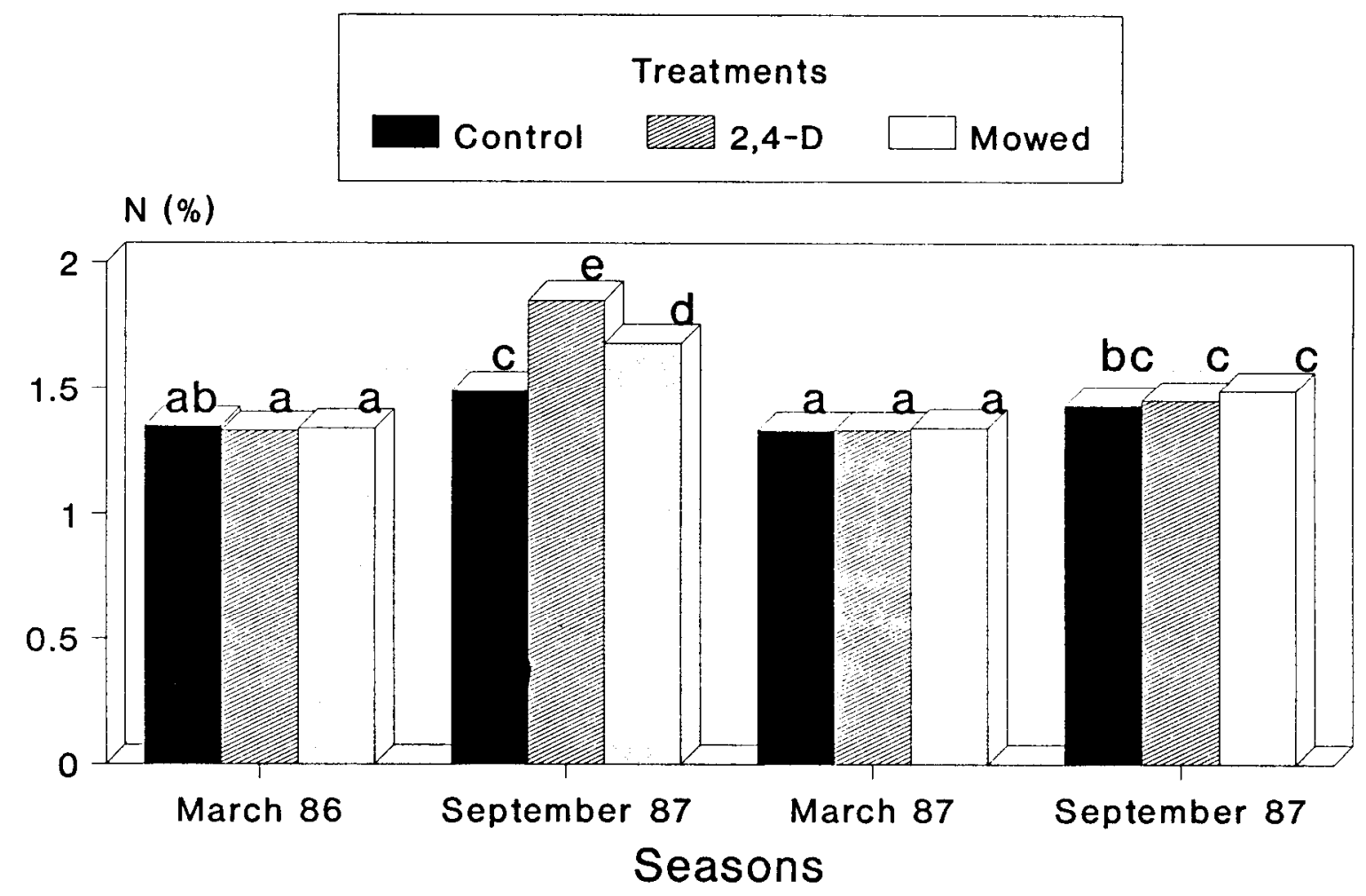

Fig. 1. Average nitrogen content $(\%)$ of antelope bitterbrush twig tips for seasons $\times$ treatments interaction. Those means topped by a different letter are significantly different at the $5 \%$ level.

and blocked into 4 relatively homogeneous replications (sites) of 4 treatments each to minimize within-replicate variation for analysis of variance (Steel and Torrie 1980).

Three permanent line transects, each 100-m long, were established in each of the 16 units, providing a total of 48 samples. Differences in treatment responses were statistically tested by analysis of variance.

\section{Treatments}

Treatments applied to 3-to 6-ha plots included 2,4,-D herbicide application, mowing, and burning. Butyl-amine of $2,4-\mathrm{D}$ at $1 \mathrm{~kg}$ acid equivalent / ha in water without surfactant at a total volume of 20 liter/ha was aerially applied in mid-May 1986. Areas were mowed to a 20 to $30 \mathrm{~cm}$ stubble height with a rotary blade shredder in late May 1986 as soil moisture conditions permitted.

Conditions were not favorable for burning in spring 1986, and only 3 areas were burned with a headfire on 16 and 17 Sep. 1986 after the herbaceous plants were dormant and sagebrush was more flammable. Relative humidity varied from 15 to $30 \%$; winds varied from 12 to $20 \mathrm{~km} / \mathrm{hr}$ from the southwest. Data from the 3 burned areas were collected after only 1 growing season in Sep. 1987 and analyzed with an analysis of variance using 3 replications of burned and unburned treatments.

\section{Data Collection}

Samples (approximately $100 \mathrm{~g}$ ) of bitterbrush twig tips, similar to those consumed by browsing animals, were collected along each transect before treatments in March 1986, in sprayed, mowed, and untreated areas in early fall (Sep. 1986), late winter (March 1987), and Sep. 1987 for laboratory analyses. Similar samples were also collected on burned areas in Sep. 1987.

Samples were dried at $50^{\circ} \mathrm{C}$ to constant weight, ground over a 40-mesh screen, and stored in airtight containers until analyzed. Analyses for ash, nitrogen, phosphorus and gross energy (A.O.A.C.
1970) were conducted on duplicate samples and the values averaged. In vitro digestible dry matter contents were determined using the technique described by Tilley and Terry (1963). Correlation analyses were conducted using plot means $(N=45)$ for the 4 forage quality factors to determine interrelationships among these factors.

\section{Results and Discussion}

Precipitation ( $58 \mathrm{~mm}$ ) in June 1986 was $190 \%$ above normal and average amounts were received during the remaining months of the growing season. During the second (1987) growing season, precipitation was below average in June and September, and about average in July, August, and October.

\section{Shrub Cover}

Total shrub foliar cover was $38 \%, 16 \%, 22 \%$, and $5 \%$ on untreated, sprayed, mowed, and burned areas in fall 1987 (Kituku 1988). Bitterbrush cover averaged about $12 \%$ on all areas and was not reduced by either spraying or mowing. Bitterbrush mortality varied from 10 to $50 \%$ on burned areas. Therefore, except for burned areas, bitterbrush nutrient yield was mostly a function of nutrient content and not bitterbrush cover. However, bitterbrush was more accessible to grazing animals on all treated areas because of the 11 to $33 \%$ reduction in sagebrush foliar cover.

\section{Nitrogen (N)}

All differences in nutrient contents or forage quality factors discussed are significant at the 5\% level of confidence unless otherwise indicated. The mean nitrogen content of untreated bitterbrush current annual growth averaged $1.34 \%$ in winter and $1.46 \%$ in late summer (Fig. 1). The mean for all seasons, treatments, and sites was $1.45 \%$ with a range from 1.3 to $1.9 \%$. The range of $0.6 \% \mathrm{~N}$ represents $40 \%$ of the mean and indicates $\mathrm{N}$ contents in bitterbrush can be manipulated with shrub management practices or may vary with phenology and environmental conditions.

Bitterbrush $\mathbf{N}$ contents in this study were within the range 


\section{Treatments}
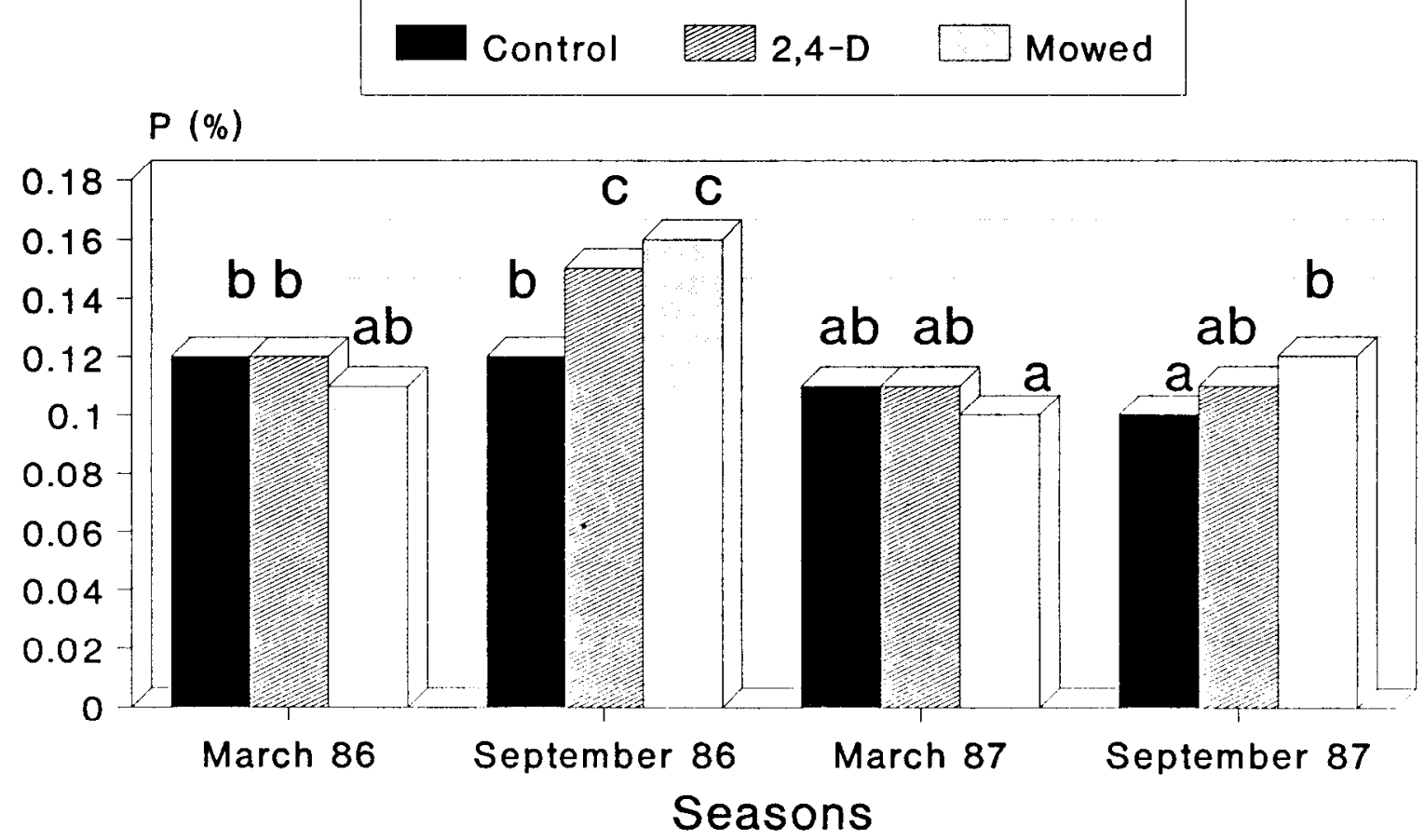

Fig. 2. Average phosphorus contents $(\%)$ of antelope bitterbrush twig tips for seasons $\times$ treatments interaction. Those means topped by a different letter are significantly different at the $5 \%$ level.

reported by Dietz et al. (1962) in Colorado on similar sites. In Nevada, $\mathrm{N}$ comprised about $2.1 \%$ of the dry weight of young bitterbrush leaves and twigs, whereas in Utah bitterbrush had $2.4 \%$ $\mathrm{N}$ in leaves and twig tips in June and 1.6\% in Sept. (Hormay 1943).

During the first growing season following treatment, bitterbrush $\mathrm{N}$ contents were $1.5 \%$ on untreated areas, $1.9 \%$ on sprayed areas, and $1.7 \%$ on mowed areas. Bitterbrush plants in sprayed areas appeared to have more leaves per stem compared to the regrowth on mowed areas. Greater leaf:stem ratios on sprayed areas may have increased the $\mathrm{N}$ content in the twig tip samples collected because of greater $\mathrm{N}$ content in leaves than in the woody portion of the twigs. In addition, root exudate and decay from shrubs killed by herbicide may produce a fertilization effect on the remaining live, associated plants (Powell and Box 1979).

During the winter and the second growing season following treatment, there were no differences in $\mathrm{N}$ contents between treated and untreated bitterbrush plants. Similar trends were reported by Everitt (1983) and Powell and Box (1965) on browse species in South Texas. Nutrient content increased in regrowth of shredded plants soon after treatment, but there were no differences in nutrient content between treated and untreated South Texas shrubs after 6 to 9 months.

\section{Phosphorus (P)}

The means for untreated bitterbrush phosphorus contents were $0.11 \%$ on all pretreated areas in March 1986, 0.12\% in Sep. 1986, and $0.10 \%$ in Sep. 1987 (Fig. 2). Differences in $P$ contents between Sep. 1986 and Sep. 1987 were significant, indicating that $P$ contents increased with increased spring precipitation.

In Utah the average winter $P$ contents of bitterbrush were 0.12 to $0.14 \%$ (Welch et al. 1983). Other shrubs commonly associated with bitterbrush have higher levels of $\mathrm{P}$ during winter (e.g., $0.22 \% \mathrm{P}$ in big sagebrush) but are less palatable than bitterbrush (Dietz 1972).

The mean $P$ content in bitterbrush for all seasons, treatments, and sites was $0.12 \%$ and ranged from $0.10 \%$ to $0.16 \%$. The range of $0.06 \%$ represents $50 \%$ of the overall mean and indicates that biologically important differences in $\mathrm{P}$ contents can occur either due to treatments, seasons, or growing conditions.

As with $\mathbf{N}$ contents, the greatest differences in bitterbrush $\mathbf{P}$ contents occurred during the first growing season following treatments. Bitterbrush $\mathrm{P}$ contents were $0.12 \%$ on untreated areas, $0.15 \%$ on sprayed areas, and $0.16 \%$ on mowed areas. There were no differences in $\mathbf{P}$ contents among treated areas during the winter season following treatments. In the second growing season following treatments, bitterbrush $P$ contents were still $0.02 \%$ greater on mowed areas than on untreated areas, but $P$ contents in bitterbrush on sprayed areas were similar to those on untreated areas.

The apparent annual variation in bitterbrush $\mathbf{N}$ and $\mathbf{P}$ contents should be studied further to determine how growing conditions affect nutrient contents. The relatively large decreases in bitterbrush P contents on sprayed and mowed areas between Sep. 1986 and March 1987 may also indicate a lack of translocation of the higher amounts of $P$ from summer leaves and twig tips into winter twig tips.

\section{Ash}

The mean ash contents in untreated bitterbrush plants were $3.0 \%$ in March 1986 prior to treatment, 3.5\% in Sep. 1986, 2.2\% in March 1987, and 3.7\% in Sep. 1987. Ash content varies with plant water content and season (Nord 1965). Our results were similar to those of Tueller (1979) who reported bitterbrush ash contents in Nevada ranging from 2.1 to $2.5 \%$ in March and from 3.3 to $4.0 \%$ in September.

The mean ash content for all seasons, treatments, and sites was $3.22 \%$, with a range of 2.4 to $3.9 \%$. The range of $1.5 \%$ or $47 \%$ of the mean indicates that ash contents also can be variable under different environmental conditions.

Significant differences in ash contents occurred between seasons 


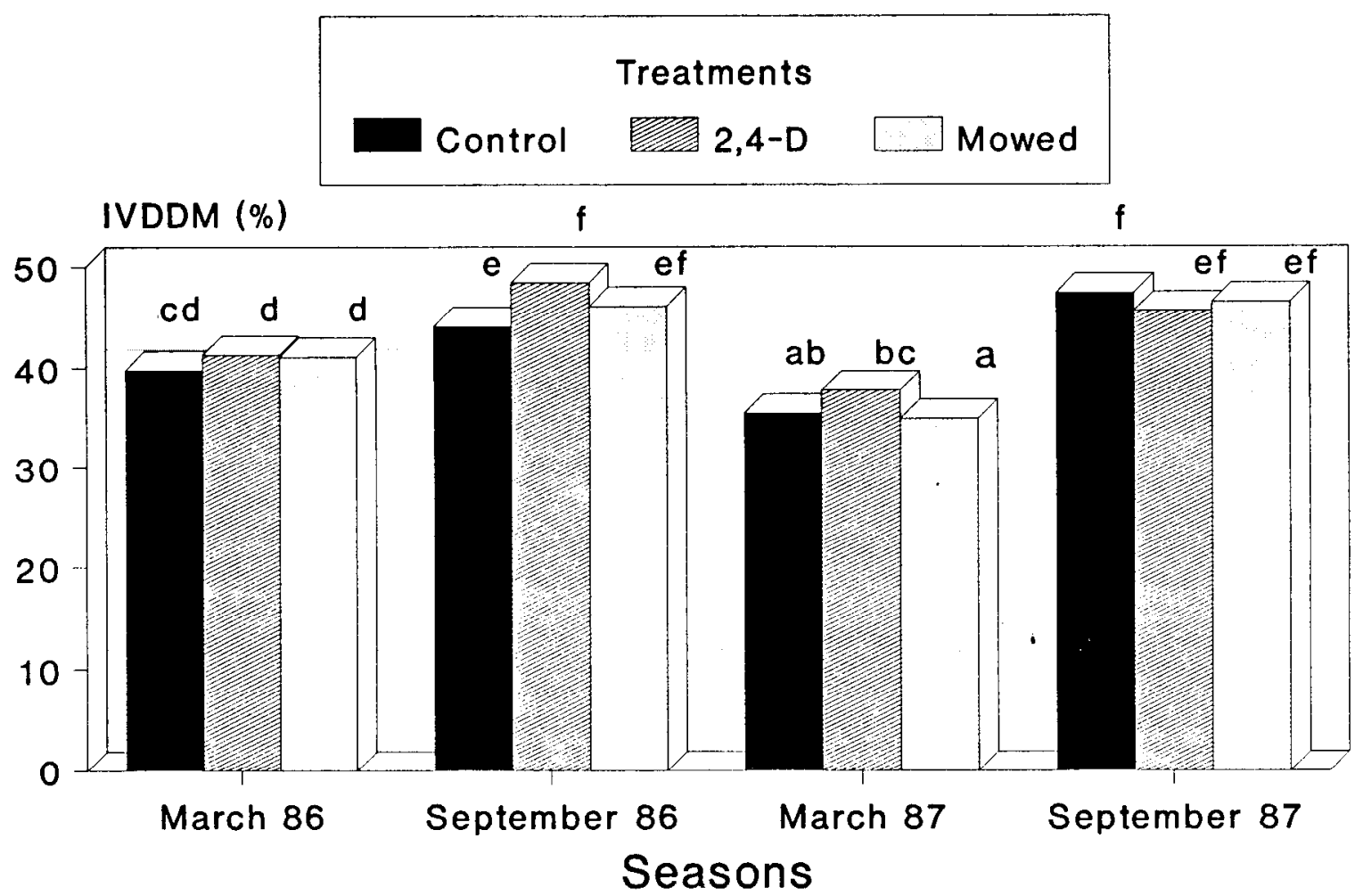

Fig. 3. Average in vitro digestible dry matter contents $(\%)$ of antelope bitterbrush twig tips for seasons $\times$ treatments interaction. Those means topped by a different letter are significantly different at the $5 \%$ level.

with higher levels in fall (3.5 to 3.7\%) and the lowest level during the relatively dry winter of $1986-87(2.2 \%)$. Ash contents were similar on all treatment areas, but tended to be lower in bitterbrush plants on sites with coarser-textured soils.

\section{In Vitro Digestible Dry Matter (IVDDM)}

The mean bitterbrush IVDDM content for untreated plants was 40\% prior to treatment in March 1986, 44\% in Sep. 1986, 35\% in March 1987, and 47\% in Sep. 1987 (Fig. 3). Digestible dry matter of antelope bitterbrush in Utah ranged from $40 \%$ to $55 \%$ with an average of $47.5 \%$ (Welch et al. 1983).

The mean IVDDM content for all seasons, treatments and sites was $42.4 \%$, ranging from 34 to $48 \%$. The range of $14 \%$ (32\% of the mean) indicates biologically important differences may occur for bitterbrush IVDDM.

The differences in IVDDM due to season were very similar to differences in ash contents, with IVDDM contents being highest during the fall and lowest during the relatively dry winter following treatments. The difference of 5\% in IVDDM between late winter 1986 and late winter 1987 may have been caused by greater winter precipitation in 1985-86 than in 1986-87. Although no differences in morphology were observed at the time of sampling, bud growth may have been more advanced in March 1986 compared to March 1987.

Bitterbrush IVDDM contents were only slightly greater on sprayed areas than on mowed or untreated areas during the fall following treatment. Bitterbrush contained $48 \%, 46 \%$, and $44 \%$ IVDDM on sprayed, mowed, and untreated areas, respectively, the first summer following treatment, and $38 \%, 35 \%$, and $35 \%$ IVDDM on sprayed, mowed, and untreated areas, respectively, the first winter following treatments.

\section{Gross Energy (GE)}

The mean bitterbrush gross energy content for all seasons and treatments was $4,680 \mathrm{kcal} / \mathrm{g}$, with a range of 4540 to $4760 \mathrm{kcal} / \mathrm{g}$.
The difference in range of $220 \mathrm{kcal} / \mathrm{g}(5 \%$ of the mean) indicates relatively little opportunity to increase GE through shrub management practices.

Bitterbrush GE was slightly higher in late winter both before and after treatment compared to the first and second fall seasons following treatment. Untreated bitterbrush contained more GE than sprayed or mowed bitterbrush only during the first fall after treatment.

Although differences in foliage GE values among sites were significant, the range $(70 \mathrm{kcal} / \mathrm{g})$ is considered to be biologically unimportant. The highest GE content occurred in bitterbrush growing on coarse-textured soils where low bitterbrush ash content also occurred. Gross energy is inversely proportional to stem growth, indicating that leaves contain higher concentration of carbohydrates, oils, and other substances yielding higher GE content than structural fiber.

\section{Burning}

Burning consumed nearly all shrub cover in burned areas, although poor fine fuel continuity in the plots resulted in a mosaic of burned and unburned areas. In the first season of growth following the burning treatment, there was profuse sprouting of bitterbrush. Twigs of bitterbrush were tender and had many large leaves.

Burned bitterbrush plants may sprout as late as 13 months after burning (Blaisdell and Mueggler 1956). Soils are warmer on burned areas and spring growth starts earlier. In this study 50 to $90 \%$ of the burned bitterbrush plants sprouted within the first growing season after the fall burn.

Compared to unburned bitterbrush twigs, regrowth twigs contained about $0.44 \%$ more $\mathrm{N}, 0.06 \%$ more $\mathrm{P}, 1.55 \%$ more ash, $3.56 \%$ more IVDDM and $260 \mathrm{kcal} / \mathrm{g}$ less GE (Table 1). The increase in N, $P$, and ash contents indicates greater leaf:stem ratios on burned plants compared to unburned plants or a fertilization effect following the burn. There was a relatively large amount of litter under all of the bitterbrush plants prior to burning. 
Table 1. Average chemical composition of antelope bitterbrush twigs in September 1987 after burning in September 1986. Untreated and burning means for all forage quality factors differ statistically at the $5 \%$ level of probability.

\begin{tabular}{|c|c|c|c|c|c|}
\hline Treatment & Nitrogen & $\begin{array}{l}\text { Phos- } \\
\text { phorus }\end{array}$ & Ash & IVDDM & $\begin{array}{l}\text { Gross } \\
\text { energy }\end{array}$ \\
\hline & \multicolumn{4}{|c|}{$\ldots \ldots(\%)-\ldots \ldots \ldots$} & (kcal/g) \\
\hline Untreated & $1.44 \mathrm{a}$ & $0.11 \mathrm{a}$ & $3.75 \mathrm{a}$ & $47.4 \mathrm{a}$ & $4640 \mathrm{~b}$ \\
\hline Burned & $1.88 \mathrm{~b}$ & $0.17 \mathrm{~b}$ & $5.30 \mathrm{~b}$ & $51.0 \mathrm{~b}$ & $4380 \mathrm{a}$ \\
\hline
\end{tabular}

\section{Nutrient Interrelationships}

The interrelationships between the levels of any 2 of the various nutrients or chemical components is shown in Table 2. All correlation coefficients are significant at the $5 \%$ level primarily because of the relative large number $(\mathrm{N}=45)$ of samples analyzed. Levels of $N$, $P$, ash, and IVDDM were directly related to each other and inversely related with GE levels.

Table 2. Correlation coefficients ( $r$ ) for selected forage quality factors in bitterbrush. All coefficients are significant at the $5 \%$ level $(N=45)$.

\begin{tabular}{lcccc}
\hline \hline & Phosphorus & Ash & IVDDM & Gross energy \\
\hline Nitrogen & 0.74 & 0.63 & 0.65 & -0.55 \\
Phosphorus & & 0.54 & 0.53 & -0.45 \\
Ash & & & 0.76 & -0.60 \\
IVDDM & & & & -0.67 \\
\hline
\end{tabular}

The highest correlation coefficients were for $\mathrm{N}$ and $\mathrm{P}(r=+0.74)$ and for ash and IVDDM $(r=0.76)$. No single forage quality factor appeared to be the best indicator of all other forage quality factors.

\section{Conclusions}

Bitterbrush nutrient contents increased during the first growing season following spraying and mowing, but the increases were relatively short-lived. Nitrogen, $\mathbf{P}$, and IVDDM contents were strongly influenced by treatment, especially burning, and were more sensitive indicators of growing conditions than were ash or GE.

This research indicates a continuous supply of high quality bitterbrush browse can be provided for livestock and wildlife by treating different, small portions of the total management area in a long-term, shrub management rotation program rather than relying on a single treatment of a large area.

Soil differences and precipitation also appear to influence bitterbrush growth and chemical composition on treated and untreated areas. Care in selecting areas to be treated should be exercised because variable results may occur under different growing conditions. Additional research is needed to better define the interrelationships between treatment effects and soil fertility, plant water stress, and plant chemical composition.

\section{Literature Cited}

Association of Official Agricultural Chemists. 1970. Methods of analysis. A.O.A.C., Washington, D.C.

Blaisdell, J.P., and W.F. Mueggler. 1956. Sprouting of bitterbrush (Purshia tridentata) following burning or top removal. Ecology 37:365-370.

Dewitt, J.B., and J.V. Derby, Jr. 1955. Changes in nutritive value of browse plants following forest fires. J. Wildl. Manage. 19:65-70.

Dietz, D.R. 1972. Nutritive value of shrubs, p. 289-302. In: C.M. McKell, J.P. Blaisdell and J.R. Goodin (eds.), Wildland shrubs-their biology and utilization. USDA Forest Serv. Gen. Tech. Rep. INT 1.

Dietz, D.R., R.H. Udall, and L.E. Yeager. 1962. Differential digestibility of nutrients in bitterbrush, mountain mahogany, and big sagebrush by deer. Nat. White-Tailed Deer Disease Symp. Proc. 1:29-36, 39-50.

Dunnewald, T.J. 1957. Wyoming soils and soils materials. Wyoming Agr. Exp. Sta. Bull. 349. Laramie, Wyo.

Everitt, J.H. 1983. Effects of plant shredding on nutrient content for four South Texas deer browse species. J. Range Manage. 36:779-781.

Giunta, B.C., R. Stevens, K.R. Jorgensen, and A.P. Plummer. 1978. Antelope bitterbrush-an important wildland shrub. Utah Div. Wildl. Resour. Pub. 78-12. Ogden, Utah.

Halls, L.K., and H.S. Crawford. 1965. Vegetation response to an Ozark woodland spraying. J. Range Manage. 18:338-340.

Hormay, A.L. 1943. Bitterbrush in California. USDA Forest Serv. Exp. Sta. Res. Note PSW 34.

Hyder, D.N., and F.A. Sneva. 1962. Selective control of big sagebrush associated with bitterbrush. J. Range Manage. 15:212-215.

Kituku, V.M. 1988. Forage value and utilization of bitterbrush (Purshia tridentata) by game and livestock. M.S. Thesis, Range Manage. Dep., Univ. Wyoming, Laramie.

Mueggler, W.F.1966. Herbicide treatment of browse on a big game winter range in northern Idaho. J. Wildl. Manage. 30:141-151.

Nord, E.C. 1965. Autecology of bitterbrush in California. Ecol. Monog. 35:307-334.

Pearson, H.A., J.R. Davis, and G.H. Schubert. 1972. Effects of wildfire on timber and forage production in Arizona. J. Range Manage. 25:250-253.

Powell, J., and T.W. Box. 1965. Brush management influences preference values of South Texas woody species for deer and cattle. J. Range Manage. 19:212-214.

Powell, J., and T.W. Box. 1979. Forage quality responses to brush management practices and fertilization in South Texas, p. 25-33. In: D.L. Drawe (ed.), The Welder Wildlife Foundation Research Program: The First 22 Years Symp. Welder Wildl. Found, Corpus Christ, Texas.

Schneegas, E.R., and S.N. Zufelt. 1965. Rejuvenating decadent bitterbrush. USDA Forest Serv. Inyo Nat. Forest, Calif. (mimeo).

Short, H.L., R.M. B lair, and L. Burkhart. 1972. Factors affecting nutritive values, p. 311-318. In: C.M. McKell, J.P. Blaisdell and J.R. Goodin (eds.), Wildland shrubs-their biology and utilization. USDA Forest Serv. Gen. Tech. Rep. INT-1.

Steel, R.G.D., and J.H. Torrie. 1980. Principles and practices of statistics. 2nd ed. McGraw-Hill Book Co., N.Y.

Tilley,J.M.A., and R.A. Terry. 1963. A two-stage technique for the in vitro digestion of forage crops. J. Brit. Grassl. Soc. 18:104-111.

Tueller, P.T. 1979. Food habits and nutrition of mule deer on Nevada ranges. Nevada Agr. Exp. Sta. Bull. R128. Reno, Nev.

Wallmo, O.C., L.H. Carpenter, W.L. Regelin, R.B. Gill, and D.L. Baker. 1977. Evaluation of deer habitat on a nutritional basis. J. Range Manage. 30:122-127.

Welch, B.L., S.B. Monsen, and N.L. Shaw. 1983. Nutritive value of antelope and desert bitterbrush, Stansbury cliffrose, and Apache-plume, p. 152-179. In: A.R. Tiedemann and K.L. Johnson (compilers), Proc. Research and Management of Bitterbrush and Cliffrose in Western North America. USDA Forest Serv. Gen. Tech. Rep. INT-152. 